\title{
AN EMPIRICAL INVESTIGATION OF THE BLACK- SCholes Call Option Pricing Model With REFERENCE TO NSE
}

\author{
Rajesh Kumar ${ }^{1}$ and Rachna Agrawal ${ }^{2}$ \\ ${ }^{1}$ Research Scholar, Department of Management Studies \\ ${ }^{2}$ Associate Professor, Department of Management Studies \\ YMCA University of Science and Technology, Faridabad, Haryana, India
}

\begin{abstract}
This paper investigates the efficiency of Black-Scholes model used for valuation of call option contracts written on Eight Indian stocks quoted on NSE. It has been generally observed that the B \& S Model misprices options considerably on several occasions and the volatilities are "high for options which are highly overpriced. Mispriced worsen with the increased in volatility of the underlying stocks. In most of cases options are also highly underpriced by the model. In this research paper, the theoretical options prices of Nifty stock call options are calculated under the B \& S Model. These theoretical prices are compared with the actual quoted prices in the market to gauge the pricing accuracy.
\end{abstract}

\section{KEYWORDS}

Black-Scholes Model, standard deviation, Mean Error, Root Mean Squared Error, Thiel's Inequality coefficient etc.

\section{INTRODUCTION}

An effective security market provides three principal opportunities- trading equities, debt securities and derivative products. For the purpose of risk management and trading, the pricing theories of stock options have occupied important place in derivative market. These theories range from relatively undemanding binomial model to more complex B \& S Model (1973). The Black-Scholes option pricing model is a landmark in the history of Derivative. This preferred model provides a closed analytical view for the valuation of European style options. An option is a contract, which gives the buyer the right, but not the obligation, to buy or sell specified quantity of the underlying assets, at a strike price on or before the expiration date. The underlying may be physical commodities like wheat, rice, cotton etc. or financial instruments like equity stocks, stock index, bonds etc. There are two types of option- call and put option. The call option gives the buyer the right to buy whereas the put option gives the right to sell. Option allows people to bet on the future events and to reduce the financial risk. There are two kinds of options- American options and European options. The former may be exercised any time before its expiration date while the later can be exercised on its expiration date. 
International Journal of BRIC Business Research (IJBBR) Volume 6, Number 2, May 2017

\section{BLACK-SCHOLES MODEL}

Fisher Black and Myron Scholes (1972) option pricing model is a landmark in the history of financial modeling. This model is used by all worldwide leading stock exchanges, investors and traders. The Black-Scholes model is based on seven assumptions-

1. The asset price follows a Brownian motion with $\mu$ and $\sigma$ constant.

2. There are no transaction costs or taxes. All securities are perfectly divisible.

3. There is no dividend during the life of the derivatives.

4. There are no riskless arbitrage opportunities.

5. Security trading is continuous

6. The risk-free interest rate is constant.

7. The option is exercised at the time of maturity (i.e., it is an European option).

The formula for the prices of European call option no dividend paying stocks (Hull, 2008)-

$$
C=\operatorname{S.N}\left(d_{1}\right)-X . e^{-r t} N\left(d_{2}\right)
$$

Where,

$$
\begin{aligned}
& \mathrm{d}_{1}=\frac{\operatorname{In}(\mathrm{S} / \mathrm{X})+\left(\mathrm{r}+0.5 \sigma^{2}\right) \mathrm{t}}{\sigma \sqrt{\mathrm{t}}} \\
& \mathrm{d}_{2}=\frac{\operatorname{In}(\mathrm{S} / \mathrm{X})+\left(\mathrm{r}-0.5 \sigma^{2}\right) \mathrm{t}}{\sigma \sqrt{\mathrm{t}}}
\end{aligned}
$$

The variables are-

$\mathrm{C}=$ Call Price of stock option

$\mathrm{S}=$ Current Stock price

$\mathrm{X}=$ Exercise price

$\mathrm{T}=$ Time remaining until expiration, expressed as a percent of a year

$\mathrm{r}=$ Current continuously compounded risk-free interest rate

$\sigma=$ The instantaneous standard deviation of stock's return.

The unknown parameter of this model is 6 . The Black-Scholes Model says that the option price, no matter it is call or put, is a function of asset price, time to maturity, exercise price, risk free interest rate and volatility of asset price. All those variables except for the volatility are easily obtainable from the market. $\sigma$ is the only unknown factor in the formula. $Б$ is assumed unchanged while calculating option prices. $\sigma$ is calculated through two approaches historical volatility and implied volatility. The historical volatility is calculated by the annualized standard deviation of historical daily returns. The historical approach is much simpler than the other one. The implied volatility looks more on the future movements. 
International Journal of BRIC Business Research (IJBBR) Volume 6, Number 2, May 2017

\section{REVIEW OF LITERATURE}

A number of researches have been carried out by the researchers to judge the pricing accuracy of the Black-Scholes model. Blattberg and Gonedes (1974) studied the impact of volatility, as one of the basic parameters, on the option price provided by the Black-Scholes model and concluded that volatility of the underlying stock is stochastic and random. Black (1975) had also identified that this model suffers from the pricing errors.

Time to maturity has also effect on the calculation of option prices under the Black-Scholes model. MacBerth and Merville (1979), using implied volatility instead of historical volatility, find that implied volatility is high for in-the-money options but the Black-Scholes model underprices these in-the-money options and secondly implied volatility is low for the out-of-the-money options but this model considerably overprices these out-of-the-money options.

Rubinstein (1985) examined the implied volatility on the 30 options classes (Chicago Board of Option Exchange) for a period of two years (from August 1976 to August 1978) and found that the short maturity options had higher implied volatility than long maturity options.

However, some researches show that discrepancies between the market option prices and prices calculated under the Black-Scholes model are not large enough to be exploited. LauterBach and Schultz (2012) on pricing warrants, Jordan and Seale (1986) and Blomeyer and Boyd (1988) on futures options written on treasury bond have suggested that there is a very little difference between the market actual price and the Black-Scholes predicted price. Bailey (1987) studied on future option written on gold, Shastri and Tandon (1986) on Future (American options), and Jordan, Seale, McCabe and Kenyon (1987) on futures options written on soyabean have found discrepancies are not enough in the model predicted prices.

Varma (2003) studies volatility, using data for a short period of time from June 2001 to February 2002, on Nifty Future and options prices under the Black-Scholes model. He suggests that the volatility is severely mispriced because of the imperfection of the Indian market and market is learning and the impact of learning effects can be seen over a long period of time.

Ramazan Gencay and Aslihan Salih (2003) compare the Black-Scholes model against the Feedforward Networks Model using S\&P 500 option Index data from January1998 to December 1993. They suggest that the Black-Scholes Model exhibits pricing error at several occasions especially for the deeper out-of-the money options compare to the near out-of-the-money options and this pricing error worsens with increased in volatility. Hence, Feedforward networks provides less pricing error as compare to the Black-Scholes model for the deeper out-of-money options.

Rinalini Pathak Kakati (2006) studied the effectiveness of Black-Scholes option pricing model in the Indian context using 2342 call and 1280 put options written from July 2001 to March 2003. She found that the Black-Scholes model misprices options considerably on several occasions. Pricing errors are negative on an average and significantly different from zero. She further suggests that mispricing worsens with both increased in moneyness and increased in the volatility of the stocks. The Black-Scholes model, according to Rinalini Pathak Kakati (2006), overprices short-term options and underprices long-term options. 
International Journal of BRIC Business Research (IJBBR) Volume 6, Number 2, May 2017

Subrata Kumar Mitra (2008) found that the Black-Scholes model exhibits pricing errors on several parameters. He suggests that the implied volatilities are high for in-the-money options and low for out-of-the-money options indicating that the Black-Scholes model underprices in-themoney options and overprices out-of-the-money options.

Mckenzie, Gerace and Sbedar (2007) studied the pricing errors produced by the Black-Scholes model using ASX 200 option Index and suggest that the use of a jump-diffusion approach and implied volatility instead of historical volatility increases the tail properties of the underlying lognormal distribution. Consequently, it increases the pricing accuracy of the Black-Scholes model $^{1}$. Rubinstein (1994) studied extensively on implied volatility under the Black-Scholes model for S\&P 500 option Index and states that the Black-Scholes model may under price options because the tail properties of underlying lognormal distribution are very small.

Emilia Vasile and Dan Armeanu (2009) have worked on the mispricing errors produced by the Black-Scholes Model for pricing options contracts. The operators take into consideration the moneyness of an option and the duration up to the due term thereof, when they calculate the volatility on account of which they evaluate the option. This is a direct consequence of the fact the Black-Scholes model cannot be applied in its original form: the prices of the financial assets do not follow log normal distribution.

Tripathi \& Gupta (2010) examined the predictive accuracy of the Black-Scholes (BS) model in pricing the Nifty Index option contracts by examining whether the skewness and kurtosis adjusted BS model of Corrado and Su gives better results than the original BS model. They have also examined whether volatility smile in case of NSE Nifty options, if any, can be attributed to the non-normal skewness and kurtosis of stock returns. Based on data of S\&P CNX NIFTY near-themonth call options for the period January 1, 2003 to December 24, 2008, their results show that BS model is misspecified as the implied volatility graph depicts the shape of a Smile for the study period. There is significant under-pricing by the original BS model and that the mispricing increases as the moneyness increases. Even the modified BS model misprices options significantly. However, pricing errors are less in case of the modified BS model than in case of the original BS model. On the basis of Mean Absolute Error (MAE), they concluded that the modified BS model is performing better than the original BS model.

V. Panduranga (2013) using Banking sector stocks on testing the efficiency of the Black-Scholes Model found that the model is applicable for banking sector stocks in India. Paired sample T-test results indicate that this model can be applied for banking stock options. However, in one out of four cases, there is a difference between expected price and market price of the option. Options may be under-priced or overpriced in the market.

Nilakantan and Jain (2014) found in their study in the context of Indian Stock market that the Black-Scholes model suffers from various deficiencies. They inferred that modified B-S Model is not able to produce efficient results for NIFTY index option in case of At-the-money, Out-ofthe Money and Deep Out-of-the-Money options. Their paper aimed at applying the corrections suggested by Corrado-Su to the Black Scholes Model using Gram-Charlier (CG) expression for option pricing in Indian market. There is a definite improvement with the Corrado-Su modified formula for equity option pricing, as compared to the original B-S formula with implied volatility. The improvement in the case of NIFTY index option pricing is $\mathrm{n}$ not much and also not 
International Journal of BRIC Business Research (IJBBR) Volume 6, Number 2, May 2017

significant. The Corrado Su adjustments seem to work well with equity options but not with index options.

\section{OBJECTIVE OF THE STUDY}

The Black-Scholes options pricing model exhibits certain biases on several parameters used in the model. This research paper has been motivated by the pricing errors produced by the BlackScholes Model. The primary objective of this research paper is to determine the efficiency of the Black \& Scholes Model in pricing Nifty stock call options.

\section{RESEARCH Methodology}

\subsection{Hypotheses}

In order to conduct the study, the researchers have formed the following hypothesis for testing:-

$\mathrm{H}_{01}$ : There is no pricing error produced by the BS model, i.e., pricing bias is zero.

$\mathrm{H}_{11}$ : There is pricing error produced by the BS model.

\subsection{Research Assumptions}

(a) Research paper has tested the stock options quoted in the NSE only.

(b) The historical option prices are considered as the closing prices.

(c) The option prices used are reliable and accurate.

(d) This research paper has assumed that the Indian option market is efficient and perfect at stated prices and the participants have the capacity to price the option correctly

\section{DAta Compilation ANd ANAlysis}

(a) Sample:

Table 1: Name of Stocks and Number of observations

\begin{tabular}{|l|l|l|l|}
\hline Stock/Year & Year 2009 & Year 2010 & $\begin{array}{l}\text { Total number of } \\
\text { observations }\end{array}$ \\
\hline ACC & 208 & 311 & 519 \\
\hline ALBK & 197 & 241 & 438 \\
\hline DLF & 379 & 444 & 823 \\
\hline AXISBANK & 295 & 354 & 649 \\
\hline GAIL & 320 & 385 & 705 \\
\hline BHEL & 354 & 367 & 721 \\
\hline SBIN & 413 & 431 & 844 \\
\hline WIPRO & 301 & 362 & 663 \\
\hline Total observations & 2467 & 2895 & 5362 \\
\hline
\end{tabular}

This research paper examines 5362 call option prices written on underlying stocks of eight companies during 2009 and 2010. The names of companies are ACC, DLF, ALBK, 
International Journal of BRIC Business Research (IJBBR) Volume 6, Number 2, May 2017

AXISBANK, BHEL, GAIL, SBI, and WIPRO. For this purpose sample consists of closing prices of 5362 Call options (observations), written on underlying stocks of eight Indian companies have been collected from the website of exchange www.nseindia.com. To bring the uniformity among the data and to reduce the effect of the time gap in closing prices, this research paper considers only highly traded options and which are expected to traded until the last moment on the concern stock exchange.

(b) Types of Data: Secondary data have been collected and used for the purpose of the calculation of the theoretical predicted premium prices as well as for the standard deviation of the stock option.

(c) Period: This research paper examines 5362 Call option prices written on underlying stocks of eight companies for a period of 2 years (from Jan. 2009 to Dec. 2010).

(d) Sources of data: The primary sources of data, time, contract month, option types, strike price and closing prices etc. are, for the purpose of this study paper have been taken from the NSE website www.nseindia.com (assessed from Jan. 2009 to Dec. 2010). The risk free interest rate used in this analysis is the 90 days retail domestic term deposit rates of SBI taken from the SBI website www.sbi.co.in (assessed from Jan. 2009 to Dec. 2010)

(e) Processing of data: The collected data have been entered under the data base and processed under the Microsoft Excel for the final calculation of the standard deviation and theoretical prices of the stock option under the Black-Scholes model. The calculated prices of call options are also cross checked by the software FUTOP version 2.0.0 used for the calculation of option prices.

(f) Time to expiry: In the above mentioned formula a term $\mathrm{e}^{- \text {-tt }}$ has been used, where, ' $\mathrm{t}$ ' is the time left for the option to expire. Here, calendar days has been used to calculate ' $t$ ', irrespective of intervening holidays. Further, ' $t$ ' is annualized by dividing ' $t$ ' by 365 days.

(g) The pricing accuracy- The pricing accuracy of stock options provided by the Black-Scholes are compared by the Mean Error (ME), Percentage Mean Error (PME), Mean Absolute Error (MAE), Mean Absolute Percentage Error (MAPE), Mean Squared Error (MSE), Root Mean Squared Error (RMSE), and Thiel's Inequality Coefficient.

\section{FINDINGS AND DISCUSSIONS}

Table 2: Entire sample measures of bias for call option based on Market Price for the year 2009 and 2010

\begin{tabular}{|l|l|l|l|l|l|l|l|}
\hline $\begin{array}{l}\text { Stocks } \\
\text { name/Errors }\end{array}$ & $\begin{array}{l}\text { Mean } \\
\text { Error } \\
\text { (ME) }\end{array}$ & $\begin{array}{l}\text { Mean } \\
\text { Percentag } \\
\text { e Error } \\
\text { (MPE) }(\% \\
\text { age) }\end{array}$ & $\begin{array}{l}\text { Mean } \\
\text { Absolute } \\
\text { Error } \\
\text { (MAE) }\end{array}$ & $\begin{array}{l}\text { Mean } \\
\text { Absolute } \\
\text { Percentag } \\
\text { e Error } \\
\text { (MAPE) } \\
(\% \text { age })\end{array}$ & $\begin{array}{l}\text { Mean } \\
\text { Squared } \\
\text { Error } \\
(\text { MSE) }\end{array}$ & $\begin{array}{l}\text { Root } \\
\text { Mean } \\
\text { Squared } \\
\text { Error } \\
\text { (RMSE) }\end{array}$ & $\begin{array}{l}\text { Thiel's } \\
\text { statistic }\end{array}$ \\
\hline ACC & -0.2004 & -2.9066 & 5.2281 & 35.0765 & 49.7104 & 7.0506 & 0.1193 \\
\hline
\end{tabular}


International Journal of BRIC Business Research (IJBBR) Volume 6, Number 2, May 2017

\begin{tabular}{|c|c|c|c|c|c|c|c|}
\hline & & & & & & & \\
\hline ALBK & $\begin{array}{l}- \\
0.0887 \\
9\end{array}$ & 0.214137 & $\begin{array}{l}1.16202 \\
3\end{array}$ & 32.40454 & 3.010431 & $\begin{array}{l}1.73505 \\
9\end{array}$ & $\begin{array}{l}0.12170 \\
8\end{array}$ \\
\hline DLF & -3.6436 & -29.1317 & 6.4359 & 60.5376 & 108.2898 & 10.4062 & 0.2095 \\
\hline $\begin{array}{l}\text { AXISBAN } \\
\mathrm{K}\end{array}$ & -7.5474 & 2.9494 & 16.6449 & 42.0912 & 562.4234 & 23.7155 & 0.2535 \\
\hline GAIL & 2.6095 & 32.3386 & 2.9663 & 35.8667 & 14.3261 & 3.7850 & 0.1335 \\
\hline BHEL & 5.5239 & 9.8620 & 14.7956 & 33.2312 & $\begin{array}{l}1083.375 \\
3\end{array}$ & 32.9147 & 0.2095 \\
\hline SBIN & -9.2356 & -21.4771 & 21.1869 & 49.9606 & $\begin{array}{l}1321.046 \\
1\end{array}$ & 36.3462 & 0.1292 \\
\hline WIPRO & 0.8200 & 3.9820 & 3.9668 & 39.1696 & 62.0364 & 7.8763 & 0.2100 \\
\hline $\begin{array}{|lr|}\text { Overall } & \\
\text { errors } & \text { for } \\
5362 & \text { call } \\
\text { options } & \\
\end{array}$ & -1.7659 & -1.6884 & 9.8083 & 42.3199 & 452.9206 & 21.2819 & 0.1590 \\
\hline
\end{tabular}

Table 3: Calculation of Standard Deviation

\begin{tabular}{|l|l|l|l|}
\hline $\begin{array}{l}\text { Stock/Standard } \\
\text { Deviation }\end{array}$ & S D for Year 2009 & S D for Year 2010 & $\begin{array}{l}\text { S D for total } \\
\text { observations }\end{array}$ \\
\hline ACC & 0.3237 & 0.2876 & 0.4578 \\
\hline ALBK & 0.4140 & 0.3667 & 0.5855 \\
\hline DLF & 1.0339 & 0.3563 & 1.4622 \\
\hline AXISBANK & 0.8472 & 0.2203 & 1.1981 \\
\hline GAIL & 0.3004 & 0.2181 & 0.4248 \\
\hline BHEL & 0.3717 & 0.1869 & 0.5256 \\
\hline SBIN & 0.5756 & 0.2318 & 0.8140 \\
\hline WIPRO & 0.3953 & 0.2782 & 0.5591 \\
\hline
\end{tabular}

The error matrices for call option have been shown in Table 2 for year 2009 and 2010. Different call options pricing errors produced by the Black-Scholes model have been calculated on eight Indian stocks as shown in table 2. The Mean Error (ME), Percentage Mean Error (PMR), Mean Absolute Percentage Error (MAPE), Mean Squared Error (MSE), Root Mean Square Error (RMSE) and Theil's inequality coefficient collectively indicate the high level of errors produced by the Black-Scholes model in pricing of the call option. Table 2 shows that the Black-Scholes 
International Journal of BRIC Business Research (IJBBR) Volume 6, Number 2, May 2017

model underprices call options in most of cases. The Black-Scholes model underprices call options with mean error of -1.7659 on several occasions. The overall errors for 5362 observations in absolute term- Mean Absolute Error (MAE) and Mean Absolute Percentage Error (MAPE) are 9.8083 and 42.3199 respectively which indicate the high level of error. Similarly the Mean Squared Error (MSE) and Root Mean Squared Error (RMSE) are also very high by 452.9206 and 21.2819 points respectively. However the option prices of ACC, DLF (by -29.1317\%) and SBIN have been underpriced while GAIL (by32.3386\%), BHEL and WIPRO have been overpriced by the model. The Overall errors for call options show that the existing model underprices option by $-1.6884 \%$. Hence in most of cases call options are underpriced by the Black-Scholes model. The Theil's inequality coefficient, used for judging about the fitness of a model, should be equal to or less than 0.1 . It is more than 0.1 indicating about the misfitness of the model.

Table 4: Analysis of different pricing errors based on the Market price for Year 2009:

\begin{tabular}{|l|l|l|l|l|l|l|l|}
\hline $\begin{array}{l}\text { Stock } \\
\text { name/Errors }\end{array}$ & $\begin{array}{l}\text { Mean } \\
\text { Error } \\
(\mathrm{ME})\end{array}$ & $\begin{array}{l}\text { Mean } \\
\text { Percentage } \\
\text { Error } \\
\text { (MPE) } \\
\text { age) }\end{array}$ & $\begin{array}{l}\text { Mean } \\
\text { Absolute } \\
\text { Error } \\
(\text { MAE) }\end{array}$ & $\begin{array}{l}\text { Mean } \\
\text { Absolute } \\
\text { Percentage } \\
\text { Error } \\
\text { (MAPE) } \\
(\% \text { age) }\end{array}$ & $\begin{array}{l}\text { Mean } \\
\text { Squared } \\
\text { Error } \\
\text { (MSE) }\end{array}$ & $\begin{array}{l}\text { Root } \\
\text { Mean } \\
\text { Squared } \\
\text { Error } \\
\text { (RMSE) }\end{array}$ & $\begin{array}{l}\text { Thiel's } \\
\text { statistic }\end{array}$ \\
\hline ACC & 2.4315 & 12.5177 & 5.7447 & 39.4747 & 58.0554 & 7.6194 & 0.1434 \\
\hline ALBK & 0.5268 & 20.8403 & 0.9798 & 35.1592 & 2.5800 & 1.6062 & 0.1432 \\
\hline DLF & -9.9001 & -88.7844 & 10.6408 & 93.2088 & 213.7722 & 14.6210 & 0.2472 \\
\hline AXISBANK & - & -34.5453 & 26.6569 & 49.8890 & 1110.997 & 33.3316 & 0.3154 \\
\hline GAIL & 2.6887 & 31.6062 & 2.9918 & 36.1079 & 15.0721 & 3.8823 & 0.1486 \\
\hline BHEL & 1.1368 & -9.2558 & 18.3167 & 32.0588 & 1974.3697 & 44.4339 & 0.2237 \\
\hline SBIN & - & -66.7055 & 30.1971 & 72.7549 & 2356.4615 & 48.5434 & 0.2041 \\
\hline WIPRO & 1.8970 & 16.1770 & 3.6622 & 30.9638 & 24.0827 & 4.9074 & 0.1360 \\
\hline
\end{tabular}


International Journal of BRIC Business Research (IJBBR) Volume 6, Number 2, May 2017

The error matrices for call option as shown in Table 4 for year 2009 show that the prices of call option of DLF (by $88.7844 \%$ ), AXISBANK (by $34.5453 \%$ ), BHEL (by $9.2558 \%$ ) and SBIN (by $66.7055 \%$ ) stocks are underpriced by the B\&S Model while the standard deviation of the same stock is relatively high. Hence, the B\&S Model undreprices high volatility stock. It pays low reward for the stock which has high volatility. Similarly the Mean Absolute Error (MAE) and Mean Absolute Percentage Error (MAPE) are very high in the all above mentioned stocks. The Theil's inequality coefficients are also very high specially in case of DLF, AXISBANK, BHEL and SBI indicating about the misfitness of the model. The values of the Theil's inequality coefficients are higher than 0.1. Hence, the null hypothesis is rejected. The Pricing bias is not zero. It is concluded that pricing error is produced by the B\&S Model on several paramenetrs.

Table 5: Analysis of different pricing errors based on the Market price for the year 2010

\begin{tabular}{|l|l|l|l|l|l|l|l|}
\hline $\begin{array}{l}\text { Stock } \\
\text { name/Errors }\end{array}$ & $\begin{array}{l}\text { Mean } \\
\text { Error } \\
\text { (ME) }\end{array}$ & $\begin{array}{l}\text { Mean } \\
\text { Percentage } \\
\text { Error } \\
(\mathrm{MPE})(\% \\
\text { age) }\end{array}$ & $\begin{array}{l}\text { Mean } \\
\text { Absolute } \\
\text { Error } \\
(\mathrm{MAE})\end{array}$ & $\begin{array}{l}\text { Mean } \\
\text { Absolute } \\
\text { Percentage } \\
\text { Error } \\
\text { (MAPE) } \\
(\% \text { age) }\end{array}$ & $\begin{array}{l}\text { Mean } \\
\text { Squared } \\
\text { Error } \\
\text { (MSE) }\end{array}$ & $\begin{array}{l}\text { Root } \\
\text { Mean } \\
\text { Squared } \\
\text { Error } \\
\text { (RMSE) }\end{array}$ & $\begin{array}{l}\text { Thiel's } \\
\text { statistic }\end{array}$ \\
\hline ACC & -1.9607 & -13.2225 & 4.8826 & 32.1349 & 44.1293 & 6.6430 & 0.1058 \\
\hline ALBK & -0.5920 & -16.6462 & 1.3110 & 30.1528 & 3.3623 & 1.8336 & 0.1124 \\
\hline DLF & 2.0983 & 25.3874 & 2.4152 & 28.8706 & 9.5832 & 3.0957 & 0.0827 \\
\hline AXISBANK & 7.7768 & 34.1951 & 8.3016 & 35.5930 & 105.2787 & 10.2605 & 0.1295 \\
\hline GAIL & 1.6768 & 32.9474 & 2.9451 & 35.6662 & 13.7061 & 3.7022 & 0.1231 \\
\hline BHEL & 9.7556 & 28.3027 & 11.3993 & 34.3620 & 223.9421 & 14.9647 & 0.1465 \\
\hline SBIN & 7.2354 & 21.8624 & 12.5530 & 28.1184 & 328.8732 & 18.1349 & 0.0572 \\
\hline WIPRO & -0.0756 & -6.1580 & 4.2202 & 45.9927 & 93.5946 & 9.6744 & 0.2503 \\
\hline
\end{tabular}

The error matrices for call option have been shown in Table 2 for year 2010. This table shows that Mean Percentage Error (MPE) of five out of eight stocks DLF(by 25.3874\%), AXISBANK (by 34.1951\%), GAIL (32.9474\%), BHEL (28.3027\%), SBIN (21.8624\%) are very high. The Mean Absolute Percentage Errors (MAPE) are also very high in all cases. The Mean Squared Errors (MSE) of seven out of eight stocks DLF (BY 9.5832\%), AXISBANK (by 105.2787\%), GAIL (by 13.7061\%), BHEL (223.9421), SBIN (by 328.8732\%) and WIPRO (by 93.5946\%) have shown high level of errors exception is ALBK stock. 
International Journal of BRIC Business Research (IJBBR) Volume 6, Number 2, May 2017

The the Theil's inequality coefficients of stock DLF and SBIN are 0.0827 and 0.0572 respectively. The case of null retention for DLF and SBIN is at the very low margin of rejection and can be discounted.

\section{CONCLUSiON}

The aim of this research was to evaluate the performance of the BS model at predicting call option prices traded in the Indian derivative market. Call Options are severely mispriced by the BS model. Mispriced worsen with the increased in volatility of the underlying stocks. The findings are somewhat consistent with the several previous empirical studies on the pricing accuracy of the BS model. There is a need to look for an alternative model for pricing option. Neural net, addressing negative cost of carry problem in B\& S Model, if appropriately designed for a given market, could be the viable alternatives.

\section{SCOPE FOR FUTURE STUdY}

The price of options calculated under the Black-Scholes model suffers from the pricing errors on several parameters used under the model. The Black-Scholes model suffers from the cost of carry problem. Since the inception of Nifty future in India, it has been observed that the Nifty Future have been trading even below the Nifty market price. If research addresses this negative cost of carry problem under the Black-Scholes model, the pricing errors can be significantly minimized.

\section{REFERENCES}

[1]. Baile, W (1987), “An Empirical Investigation of the Market for comex Gold Future Options”, Journal of Finance, Vol. 42, No. 5, pp 1187-1194.

[2]. Black F (1975), "Fact and Fantasy in the use of options". Financial analyst journal, vol. 31, pp. 36-41

[3]. Black F, and Scholes M (1972), "The valuation of option contracts and a test of market efficiency", Journal of Finance, vol. 27

[4]. Blomeyer, E and Boyd, J (1988), "Empirical Test of Boundary Conditions for Options on Treasury Bond Futures", The Journal of Futures Markets, Vol. 8, pp 185-198.

[5]. Gencay Ramazan and Salih Aslihan (2003), "Degree of mispricing with the Black-Scholes model and nonparametric cures", Annals of Economics and Finance, 4, pp. 73-101,

[6]. Hull JC (2007), "Options, Futures, and other Derivatives", Sixth Edition, Pearson prentice- Hall, India.

[7]. Jordan J V, Seale, W E, McCabe, N C and Kenyon (1987), "Transaction Data Tests of the Black model for Soyabean Futures option”, The Journal of Future Markets, Vol. 7, No. 5, pp 535-554

[8]. Jordan J V, and Seale, W E (1986), "Transaction Data Tests of Minimum Prices and Put Call Parity for Treasury Bond Future Options", Advances in Futures and Options Research, Vol. 1, pp 63-87.

[9]. K P Rinalini (2006), "Effectiveness of the Black-Scholes Model for Pricing Options in Indian Option Market", The ICFAI Journal of Derivatives Market, PP 6-19.

[10]. LauterBach, B and Schultz, P (2012), "Pricing Warrants: An Empirical Study of the Black-Scholes Model and Its Alternatives", The Journal of Finance, Vol. 45, 1181-1209 
International Journal of BRIC Business Research (IJBBR) Volume 6, Number 2, May 2017

[11]. MacBeth J D and Merville L J (1979), “An Emperical Examination of the Black-Scholes Call Option Prices", Journal of Finance, vol. 34, pp. 1173-1186.

[12]. Mckenzie Scott, Gerace Dionigi Gerace and Subedar Zaffar (2007), “An Empirical Investigation of the Black-Scholes Model: Evidence from the Australian Stock Exchange, The Australasian Accounting Business \& Finance Journal, pp page 71

[13]. Mitra, S K (2008), "Valuation of Nifty Options Using Black’s Option Pricing Model”, The ICFAI Journal of Derivatives Market. PP 51-61

[14]. Rubinstein M (1985), "Non-parametric Test of Alternative Option Pricing Models Using all Reported Trade and quotes on the 30 Most Active CBOE Option Classes from August 23, 1976 Through August 31, 1978", Journal of Finance, Vol. 40, N0. 2, pp 445-480.

[15]. Shastri, K and Tandon, K (1986), “An Empirical Test of a Valuation Model for American Options on Futures Contracts", Journal of Financial and Quantitative Analysis, Vol. 21, Issue 04, pp 377-392

[16]. Thiel H (1961), Economic Forecast and Policy, $2^{\text {nd }}$ Revised Edition, North Holland Publishing co., Amsterdam

[17]. Varma, VR (2003), "Mispricing of Volatility In the Indian Index Options Market” Working paper, IIM Ahmedabad 